\title{
Alexander the Great's Characteristics, from the Perspective of The Battle of River Granicus
}

\author{
Qinyan Tong
}

\author{
ASUS from Suzhou Ulink College of Suzhou Industrial Park, Suzhou, Jiangsu 215000, China \\ cindytong01014321@Gmail.com
}

\begin{abstract}
Alexander the Great was known as one of the most remarkable and influential people in Greek history and later European history. His actions shall improve our understanding of Greek culture tremendously. As the Primary resource proved to be scarce under the circumstances of too antique, in contrast, the analysis of modern scholars is more crucial than other periods in history. This paper aimed to analyze human civilization development of the particular region (Greek), from the perspective of a pivotal person, regarding a specific action, which reflects his personality. This paper analyzed the disagreements between Alexander the Great and his greatest general, one of his most recognized generals, Parmenio. By referring to the different decisions that Alexander could have made, and the various actions that Alexander really took, which were argued in extra reliable primary resources agreed in the Ancient Greek history community. This paper provides analyses supporting that Alexander was wiser as a king than as a general, for he is more excellent in raising the morale of soldiers, which is a long-run benefit, than winning a simple battle; however, he was proved to be professional in both areas, just he saw more significant needs in raising the morale of soldiers. The paper used desk research, regarding the primary and secondary sources that had been used in the research process. Hopefully, within the explanations given in this paper, people would have one more perspective to think about the disagreement, develop a higher understanding of Alexander the Great. Moreover, students could learn from him about the decision-makers considering risks when facing, about how to have a broader aspect, think out of the box, other's interest, predict other's actions, extra.
\end{abstract}

Keywords: Alexander the Great, Parmenio, Disagreement, Leadership, Risk-taking, Anticipation for other's decision

\section{INTRODUCTION}

In the past story of Alexander the Great taming Bucephalus, people had started to notice that the young man of Macedon could see things that other people could not. Other than that, another example that Plutarch used to testify the characteristics of Alexander was that just before the Battle of Granicus, Alexander and his general Parmenio had some disagreements of whether they should attack the Persian army just when they arrived or stay for the night. The actions that Alexander the Great took were seen as rather an obstruction. [1] As Plutarch believed that the characteristics of a man are more decisive and crucial, "minors conflicts" like the argument between Alexander and Parmenio do count as a demonstration of the glorious Alexander. [2]In this essay, I will determine the background information about how the Battle of Granicus River was so important, what was the Amy forces of both sides, what the battle was like, and eventually, what was the aftermath of the fight. However, the real focus was on the disagreement between Parmenio and Alexander the Great. When they had come across the Hellespont, initially there were about 47000 people who had finished the job[3], but in fact, the number was too large that the wealth that they had carried with them could not afford a more protracted battle more than a month or so. [4] The economic issue motivated the Macedonians to overtake a vital city to feed the population. In the meanwhile of marching toward the grand army of Darius, some of the defenseless tribes were forced to submit to the Macedonians.[5]Apparently, the few treasures that those tribes had were too little to solve the economic problem. A Greek general, Memnon, who served the Persian king.A great Army like the one Alexander brought, would surrender easily if the supply line had been cut. [6]If the plan was taken by the Persian king, the Macedonian army would have been defeated, 
but he did not trust Memnon. Finally, the grand Persian army was built just as Alexander wanted them to do.

\section{SITUATION OF ARMIES}

Historians have argued that the number of actual soldiers that each side had, unfortunately after centuries, the accurate number was tough to estimate. Overall, the Macedonian army proved to have about 35000-50000 men, and the Persian army had about 35000to to 40000 men.[7] Though that the numbers today do not have that much academic solid evidence to support their ideas, the majority of historians do believe that the Macedonian army had a slight advantage in terms of soldiers. Some people also argued that there were about 10000 Macedonians that were already in the region waiting for Alexander to arrive. [8]On a smaller scale, the Persians had less infantry power, but the cavalry forces should not be ignored. [9]They had planned how to use their advantages in the battle, as will be written in the following paragraph.

\section{PRE BATTLE OF THE RIVER GRANICUS}

Now the Persian armies were on one side of the River Granicus, probably with a distance so that it is easier for them to attack the Greek troops right after they crossed and landed on the shore of river Granicus. Parmenio had a disagreement with Alexander on whether they should attack the Persian army right away or wait for dawn. [10] There are disagreements between whether or not the Macedon army attacked just then or immediately, but from the timeline and my personal understanding of Alexander the Great, he did lead the military to Darius just when they arrived. The heavy infantry forces of the Macedonian army were all placed in the middle, trying to face the main power of the Persian influence and to maximize the advantage of heavy infantry. [11]The leftwing cavalry was led by Armenia, a small group on one side of the infantry. The other side was also the cavalry but led by Philotas, son of Parmenio. [12]The Persian cavalry was placed along the side of the river Granicus, and the infantry was separated into three-piece, right along just behind the cavalry forces, aiming to strengthen the cavalry enhancement. [13]After they saw how the Greeks had placed their army, they changed the arrangements. [14]Now there is only one unit of Calvary in the middle, and the infantry was seated right behind it. There were three units of cavalry to the side that Alexander the Great the king was in, and two to the right where Parmenio and his companion cavalry was headed. [15]

\section{DURATION OF THE BATTLE OF GRANICUS}

As the Macedonians were crossing the river, the three parts of the battlefield soon began to get intense. [16] The three parts directly faced the other side just like both sides anticipated to be. However, this way, the chances that Alexander would win are not that big, so he had a little "surprise" for the Persian army. He did not face the leftwing of the Persian cavalry like the Persians wanted them to do; they turned to the middle and the center of the Persian army. They moved faster than the Infantry of the Macedonians. Hence there was a time that the Companion cavalry was facing a three-fronted battle; it was indeed fierce, too fierce that Alexander was almost killed. When Alexander was about to be stabbed in the back by a Persian rider, Alexander's personal bodyguard Cleitus killed the Persian, resulting from the thrilling narrow miss. [17] Right after the farce ended, the infantry finally crossed the river and joined the fight. The infantry pushed the Persian cavalry backward, giving some relief to the cavalry, and the probably wounded Alexander was soon back on his horse again. [18] Due to the advantages that the Greek infantry had, they soon had control of the battlefield. Lucky enough, the Companion cavalry of the leftwing of the Greek army had just finished up with the Greek cavalry that they were directly facing. Hence they joined the fight in the middle. [19] As the clarity that things had become, it is easy to predict the triumph of the Macedonian army. The exciting thing is that although most of the Persian army had retreated, the Greek mercenaries did not; they asked for the forgiveness of Alexander the Great in order to surrender. [20,21]Alexander did not agree; my personal understanding is that this was taken as a test for his courage and bravery. Perhaps he does not believe that the losing side had the right to bargain, especially when the winning of the battle Is almost definite by the time. However, thanks to his impertinence, he had lost one of his horses and knocked down the horse, and that does actually matter since he's the leader of the country and the head of the army. Though, yes, he did win the battle. [22]

\section{ANALYSIS OF THE DISAGREEMENT}

My personal interest was in the disagreement. Parmenio thought that as soon as the Persians found out that they were outnumbered, they would retreat and wait for backup forces.[23]Parmenio also felt that having a grand battle in the middle of a muddy river could violate the advantage that they had a strong infantry. Since the Persians had a more potent Cavalry force which seemed like an enhancement to the Persian army in battles fought in the middle of the river, significantly when they were outnumbered. However, Alexander the Great actually did the exact opposite. He said that they had come through so many things and gone this far already. They should not be slowed down and stopped by the little stream that could barely influence them. That was the second time that Alexander the Great had shown his leadership and 
how he could see things differently than others. The first time was when he tamed Bucephalus.

\section{FURTHER DISCUSSION OF THE DISAGREEMENT}

Historians argued that Alexander made the decision using more emotions other than careful thinking of logic. However, from what my understanding of leadership is, if Alexander waited, yes, the army would probably have still won the battle, but the heart of the Macedonian army would not be the same. Alexander was known as a good leader, both political and on the battlefield, but his success could not have been this remarkable without his grand army. The emotions and the morale of the soldiers sometimes lie a more important status than the number of the soldiers. It is not that there were no examples that Alexander won the battle even with fewer soldiers on the Macedonian side. He may or may not have thought about it so clearly, but his actions told us that he already began to notice that quantity does not mean destined victory. One thing that Alexander was so obsessed with was making sure that the army always knew that they were going to win. He wanted the military to feel his passion so that they would fight with love, just like him in the battle. Alexander realized that winning a war was undoubtedly important, but the morale of soldiers was just as important. The passion that he wanted them to feel the needed time to support. He would gladly give some chances of winning away to make sure that the morale of the soldiers was passionate. Not to mention that they do not have $100 \%$ winning possibility if they waited for dawn, and they would not definitely fail if attacked right away. In Alexander's subconsciousness, they were winning a battle if remained is just like winning using sophisticated tactics. Alexander is not a person that does not want to take any risks. In fact, we all know that higher risk makes a higher profit, and a good leader knows what kind of risks are wise to take. It is not wrong that people say that Alexander made the decision by more emotions than exquisite thinking, but Alexander actually had this sense deep inside his subconsciousness; he had thought about those psychological aspects in the second that he was facing the choice. That is also a property that we say that destined the fate of Alexander been the king of Asia.

\section{AFTERMATHS OF THE BATTLE OF RIVER GRANICUS}

Finally, the estimate of losses in the battle of River Granicus, historians actually debate about it all the time, the few antique sources that the modern historians had access to, provided different answers each had various suspicious biases. Plutarch mentioned in his book that there were only about 34 people that were killed in the battle; 8 of them were infantry. [24] The number was considered too few, the way that the struggle had been having made a found foundation to an uncontrollable death rate, hence the casualties could have been exaggerated few. Alexander had ordered to build memorials for each and every of the sacrificed soldiers. Alexander had also called he send some of the shields of the defeated Persians back to Athens with the inscription translated to English "Alexander, son of Philip, and the Greeks, except the Spartans, dedicate these spoils, taken from the barbarians who dwell in Asia." [25] That was the famous shield inscription event. It was told that it was an answer to the Athenians, for they had punished the Persians for burning down the temple of Athens in 480 B.C. The language on the shield was, in fact, Greek; it was told and speculated to be the propaganda of Alexander to spread the words of his victory. That was indeed success in River Granicus. The aftermath that was right after the battle was listed above. However, the Shield inscription was an exciting topic, but not what I chose to focus on for this paper.

\section{CONCLUSION}

The Battle of River Granicus was undoubtedly a spectacular start for Alexander the Great, who was a king in his 20s. Historians have been mostly debating over the disagreement between Parmenio and Alexander the Great. In my opinion, Alexander the Great really seldom did things that were wrong; more likely, he had other plans, or the whole Greek culture did not develop the sense. Overall, Alexander focused more on the morale of soldiers instead of winning one battle, especially when Alexander thought that their strategy of the fight would lead them to victory. Hence Alexander chose to be a good leader instead of a general, who focuses more on the winning of the battle. He thought is would be better if he can motivate the soldiers, to promote them to fight with passion and glory, the results will be better when they waited for dark. Alexander is a person that do things with bravery, otherwise he wouldn't have such glamorous results. This is a way that he persuade people that he is the one they should follow, included as leadership.

\section{REFERENCES}

[1] Arrian (2013), book 1 chapter 13, M. Hammond \&amp; J. John Atkinson, Trans, Alexandre the Great, Oxford University Press, Oxford, 1

[2] Plutarch(2021), book 1 chapter 7, LacusCurtius, Life of Alexander the Great, uchicago.edu, Chicago, 1

[3] Historia Civilis, 2019. The Battle of the Granicus, [online] Available at: $<$ https://www.youtube.com/watch?v=Idw_3WnIqn c> [Accessed 27 August 2021].

[4] Arrian (2013), book 1 chapter 12, M. Hammond \&amp; J. John Atkinson, Trans, Alexandre the Great, Oxford University Press, Oxford, 9 
[5] Historia Civilis, 2019. The Battle of the Granicus, [online] Available at: <https://www.youtube.com/watch?v=Idw_3WnIqn c> [Accessed 27 August 2021].

[6] Arrian (2013), book 1 chapter 12, M. Hammond \&amp; J. John Atkinson, Trans, Alexandre the Great, Oxford University Press, Oxford, 9

[7] Historia Civilis, 2019. The Battle of the Granicus, [online] Available <https://www.youtube.com/watch?v=Idw_3WnIqn c> [Accessed 27 August 2021].

[8] Historia Civilis, 2019. The Battle of the Granicus, [online] Available at: <https://www.youtube.com/watch?v=Idw_3WnIqn c> [Accessed 27 August 2021].

[9] Historia Civilis, 2019. The Battle of the Granicus, [online] Available at: <https://www.youtube.com/watch?v=Idw_3WnIqn c> [Accessed 27 August 2021].

[10] Arrian (2013), book 1 chapter 12, M. Hammond \&amp; J. John Atkinson, Trans, Alexandre the Great, Oxford University Press, Oxford, 9

[11] Arrian (2013), book 1 chapter 13, M. Hammond \&amp; J. John Atkinson, Trans, Alexandre the Great, Oxford University Press, Oxford, 1

[12] Arrian (2013), book 1 chapter 14, M. Hammond \&amp; J. John Atkinson, Trans, Alexandre the Great, Oxford University Press, Oxford, 1

[13] Arrian (2013), book 1 chapter 14, M. Hammond \&amp; J. John Atkinson, Trans, Alexandre the Great, Oxford University Press, Oxford, 4

[14] Historia Civilis, 2019. The Battle of the Granicus, [online] Available at: <https://www.youtube.com/watch?v=Idw_3WnIqn c> [Accessed 27 August 2021].

[15] Historia Civilis, 2019. The Battle of the Granicus, [online] Available at: <https://www.youtube.com/watch?v=Idw_3WnIqn c> [Accessed 27 August 2021].

[16] Historia Civilis, 2019. The Battle of the Granicus, [online] Available at: <https://www.youtube.com/watch?v=Idw_3WnIqn c> [Accessed 27 August 2021].

[17] Arrian (2013), book 1 chapter 15, M. Hammond \&amp; J. John Atkinson, Trans, Alexandre the Great, Oxford University Press, Oxford, 8

[18] Historia Civilis, 2019. The Battle of the Granicus, [online] Available at: <https://www.youtube.com/watch?v=Idw_3WnIqn c> [Accessed 27 August 2021].
[19] Arrian (2013), book 1 chapter 16, M. Hammond \&amp; J. John Atkinson, Trans, Alexandre the Great, Oxford University Press, Oxford, 2

[20] Arrian (2013), book 1 chapter 16, M. Hammond \&amp; J. John Atkinson, Trans, Alexandre the Great, Oxford University Press, Oxford, 2

[21] Plutarch(2021), book 1 chapter 16, LacusCurtius, Life of Alexander the Great, uchicago.edu, Chicago,

[22] Historia Civiclis, 2019. The Battle of the Granicus, [online] Available at: <https://www.youtube.com/watch?v=Idw_3WnIqn c> [Accessed 27 August 2021].

[23] Arrian (2013), book 1 chapter 13, M. Hammond \&amp; J. John Atkinson, Trans, Alexandre the Great, Oxford University Press, Oxford, 1

[24] Historia Civilis, 2019. The Battle of the Granicus, [online] Available at: <https://www.youtube.com/watch?v=Idw_3WnIqn c> [Accessed 27 August 2021].

[25] Arrian (2013), book 1 chapter 16, M. Hammond \&amp; J. John Atkinson, Trans, Alexandre the Great, Oxford University Press, Oxford, 7 